\title{
Casing Material and Thickness Effects on the Yield and Nutrient Concentration of Agaricus bisporus
}

\author{
Kamran Ghasemi ${ }^{1 *}$, Mostafa Emadi ${ }^{2}$, Asghar Bagheri ${ }^{3}$ and Mehdi Mohammadi ${ }^{1}$
}

${ }^{1}$ Department of Horticulture, Faculty of Crop Sciences, Sari Agricultural Sciences and Natural Resources University, Sari, Iran; ${ }^{2}$ Department of Soil Sciences, Faculty of Crop Sciences, Sari Agricultural Sciences and Natural Resources University, Sari, Iran; ${ }^{3}$ Genetics and Agricultural Biotechnology Institute of Tabarestan, Sari Agricultural Sciences and Natural Resources University, Sari, Iran.

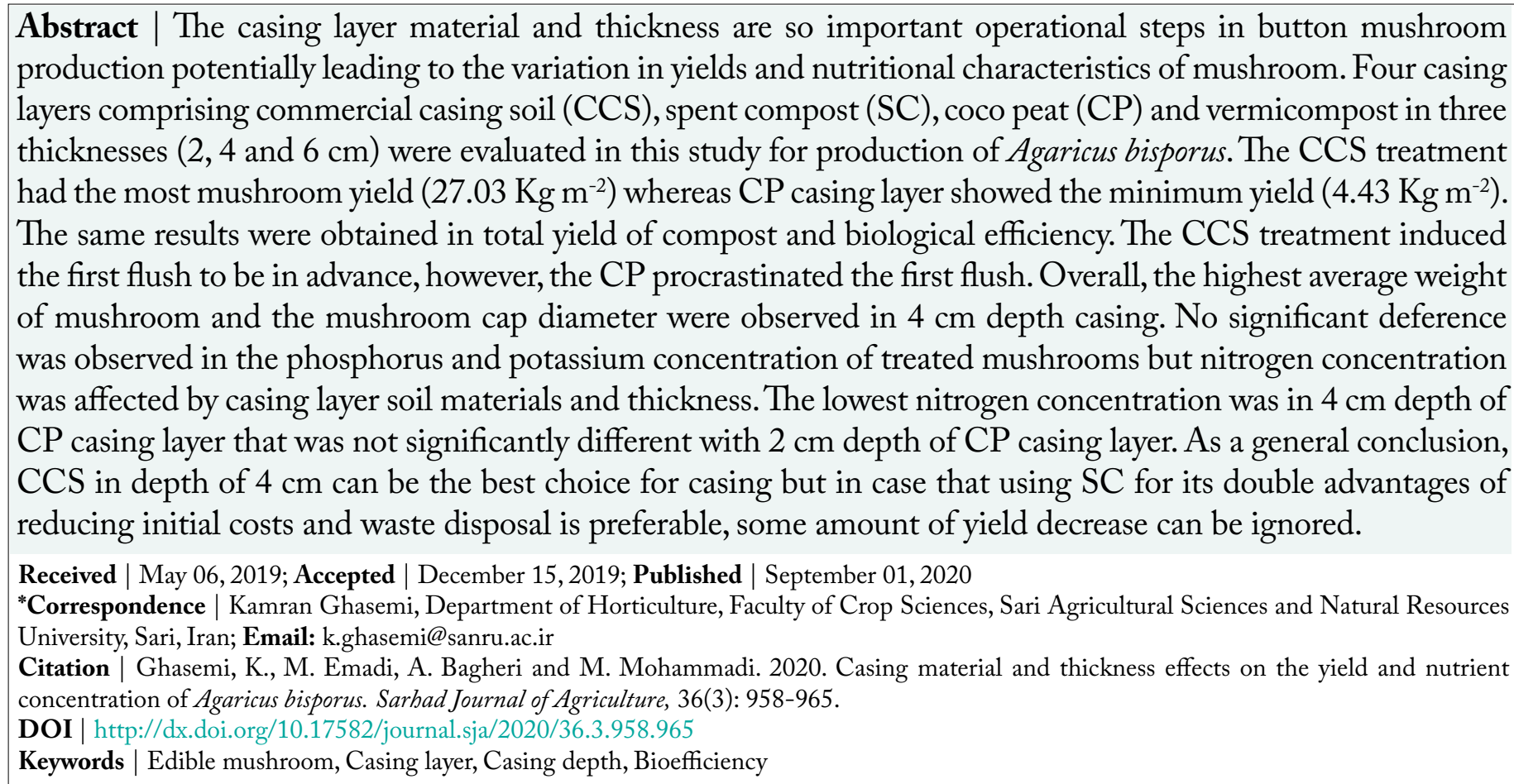

\section{Introduction}

$\mathrm{T}$ he casing layer soil is one of the most essential operations inbutton mushroom(Agaricusbisporus) production. Casing layer soil is commonly used for covering the compost immediately after mycelium colonialization (spawn run), to promote the mycelium to be fructified (Pardo-Giménez and Pardo-Giménez, 2008). Based on different studies, peat is the best option to use for casing layer (Rainey and Cole, 1987), but it is nonrenewable substance and so expensive in Iran.
Materials with high water holding capacity can likely be good alternative of peat especially if be cheap and easily available. The perfect material for casing layer should provide appropriate conditions for mycelium and facilitate the transformation vegetative to reproductive stage (Flegg et al., 1985). Casing material should have enough porosity for mycelial respiration, high water retention to insure mycelium growth, and resistant physical structure for stabilization following frequent watering (Noble and Dobrovin-Pennington, 2005). 
Gulser and Peksen (2003) studied the potential of tea waste as a new casing material and recommended the mixture of tea waste with peat in 1:1 (v:v) ratio for casing layer. Coconut fibre (coir) is a good alternative for peat substitution which can be combined with other materials using as an efficient casing layer (Pardo-Giménez and Pardo-Giménez, 2008). Pardo-Giménez and Pardo-Giménez (2008) proposed that the spent mushroom substrate can be an ingredient of casing material for mushroom cultivation. Vermicopmost is another casing material for mushroom cultivation (Pani, 2012). Colauto et al. (2010) demonstrated that lime schist can be a viable substrate as a casing layer in Agaricus brasiliensis production. They claimed this material increases Agaricus brasiliensis productivity up to $92 \%$ compared to the subsoil with charcoal (as a control).

In an interesting research Nadi et al. (2015) reused casing layer in combination with fresh casing at different ratios and reuse it alone as well. The results were surprising due to no significant difference among treatments. Based on these results they suggested reusing of casing layer without any problem, but $\mathrm{pH}$ and salinity regulation of materials accompany with disinfecting against pathogens is essential.

There is still a little information about the best depth of casing layer and its effect on quantity and quality of edible mushrooms specially Agaricus bisporus. Pani (2012) evaluated five casing layer depth including $1,2,3$, and 5 inches in milky mushroom (Calocybe indica) cultivation and indicated that the depth of 2 inch led to the highest yield. However, Subramanian and Shanmugasundaram (2015) reported that the casing layer thickness of $2.5 \mathrm{~cm}$ could be the best for obtaining high yield and bioefficiency of milky mushroom in comparison with thickness of 1.5 and $3.5 \mathrm{~cm}$.

Due to the importance of sustainable and economical agriculture, finding an environmental friendly materials or reuse the commercial casing soil is vital. Considering the variability of results obtained by previous studies, this research tried to test the performance of different materials and thicknesses of casing layer soil for Agaricus bisporus production. Moreover, this study was aimed to evaluate different types of casing layers as an alternative of nonrenewable and expensive materials.

\section{Materials and Methods}

\section{Mushroom cultivation and casing treatment}

Packed spawned compost in the plastic bags $\left(55 \times 35 \times 10 \mathrm{~cm}^{3}\right)$ was supplied by Javane Tabarestan Corporation, Mazandran province, Iran. All the compost bags were placed in a same environmental condition. Four casing layer comprising commercial casing soil (CCS), spent compost (SC), coco peat (CP) and vermicompost in three thicknesses (2, 4 and $6 \mathrm{~cm}$ ) were evaluated in this study. The important physical and chemical properties of casing materials including total nitrogen, phosphorus and potassium contents, as well as water holding capacity, saturated moisture percentage, particle density, $\mathrm{C} / \mathrm{N}$ ratio, electrical conductivity, and $\mathrm{pH}$ were determined and shown in Table 1. In spawn run phase, the temperature was kept around $25^{\circ} \mathrm{C}$ and the relative humidity was monitored around $80-85 \%$. After mycelium came out and covered the surface of compost, casing material was added to the system in three thicknesses as treatments.

\section{Determination of parameters}

Yield and yield components: All commercial grown mushrooms were harvested twice in a week and total yield was determined as $\mathrm{kg}$ per $\mathrm{m}^{2}$. Number of mushrooms in each square meter was recorded during the experiment period. To test the performance of treatments on the size of the produced mushrooms, cap diameter was also determined. The average weight of mushroom was calculated as total yield divided by total mushroom number in each square meter area. Exactly $100 \mathrm{~g}$ of fresh mushrooms was dried till stable weight at the $70^{\circ} \mathrm{C}$ and then weighed again to calculate the dry matter of mushrooms. The earliness that is the number of days from casing application till the first harvest was also evaluated. Total yield of compost and biological efficiency was calculated using following formulas (Zied et al., 2012):

$$
\begin{aligned}
& \text { Total yield of compost }(\%)=\frac{\text { Yield of fresh mushroom }(\mathrm{g})}{\text { fresh weight of the compost }(\mathrm{g})} \times 100 \\
& \text { Biological efficiency }(\%)=\frac{\text { Yield of fresh mushroom }(\mathrm{g})}{\text { dry weight of the compost }(\mathrm{g})} \times 100
\end{aligned}
$$

Mineral nutrients: nitrogen $(\mathrm{N})$, phosphorous $(\mathrm{P})$ and potassium $(\mathrm{K})$.

The mushroom samples were oven dried at $70{ }^{\circ} \mathrm{C}$ and crushed into the powder form to determine mineral nutrients including $\mathrm{N}, \mathrm{P}$ and $\mathrm{K}$. The method of Chapaman and Pratt (1961) was used for digestion 
Table 1: Physical and chemical properties of used casing materials.

\begin{tabular}{|c|c|c|c|c|c|c|c|c|}
\hline Casing material & $\mathbf{N}(\%)$ & $\mathbf{P}(\%)$ & K (\%) & $\begin{array}{l}\text { Water holding } \\
\text { capacity (\%) }\end{array}$ & $\begin{array}{l}\text { Particle density } \\
\left(\mathrm{g} \mathrm{cm}^{-3}\right)\end{array}$ & $\mathrm{C}: \mathrm{N}$ & $\begin{array}{l}\mathrm{EC} \\
\left(\mathrm{dS}_{\mathrm{m}^{-1}}\right)\end{array}$ & $\mathbf{p H}$ \\
\hline Commercial casing soil & 1.40 & 0.195 & 0.267 & 140.27 & 1.95 & 14.19 & 3.56 & 7.14 \\
\hline Spent Compost & 1.31 & 0.951 & 0.896 & 89.27 & 11.68 & 11.01 & 7.52 & 7.85 \\
\hline Coco peat & 2.41 & 0.061 & 0.797 & 533.00 & 3.94 & 15.25 & 2.99 & 5.85 \\
\hline Vermicompost & 5.11 & 0.383 & 0.268 & 70.31 & 1.88 & 2.25 & 1.32 & 7.83 \\
\hline
\end{tabular}

Table 2: Effect of casing layer on the yield and yield components of button mushroom.

\begin{tabular}{|c|c|c|c|c|c|c|c|c|}
\hline $\begin{array}{l}\text { Earliness } \\
\text { (days from } \\
\text { casing) }\end{array}$ & $\begin{array}{l}\text { Dry } \\
\text { matter } \\
\%^{\text {ns }}\end{array}$ & $\begin{array}{l}\text { Average cap } \\
\text { diameter } \\
(\mathrm{cm})^{\mathrm{ns}}\end{array}$ & $\begin{array}{l}\text { Average weight } \\
\text { of mushroom } \\
(\mathrm{gr})^{\mathrm{ns}}\end{array}$ & $\begin{array}{l}\text { Number of } \\
\text { mushrooms } \\
\text { in one } \mathbf{m}^{-2}\end{array}$ & $\begin{array}{l}\text { Biological efficien- } \\
\text { cy ( } \mathrm{kg} 100 \mathrm{~kg}-1 \\
\text { dried compost) }\end{array}$ & $\begin{array}{l}\text { Total yield of com- } \\
\text { post }(\mathrm{kg} 100 \mathrm{~kg}-1 \\
\text { fresh compost) }\end{array}$ & $\begin{array}{l}\text { Yield } \\
\left(\mathrm{Kg} \mathrm{m}^{-2}\right)\end{array}$ & Treatments \\
\hline $38.78 \mathrm{c}$ & $7.56 \mathrm{a}$ & $4.93 \mathrm{a}$ & $36.07 \mathrm{a}$ & $780.6 \mathrm{a}$ & $68.42 \mathrm{a}$ & $26.02 \mathrm{a}$ & $27.03 \mathrm{a}$ & $\begin{array}{l}\text { Commercial } \\
\text { casing soil }\end{array}$ \\
\hline $41.56 \mathrm{~b}$ & $7.99 \mathrm{a}$ & $4.86 \mathrm{a}$ & $33.85 \mathrm{a}$ & $541.7 \mathrm{ab}$ & $44.81 b$ & $17.04 \mathrm{~b}$ & $17.71 \mathrm{~b}$ & Spent compost \\
\hline 49.89 a & $6.91 \mathrm{a}$ & $5.97 \mathrm{a}$ & $43.04 \mathrm{a}$ & $144.4 \mathrm{c}$ & $11.22 \mathrm{c}$ & $4.27 \mathrm{c}$ & $4.43 c$ & Coco peat \\
\hline $42.12 \mathrm{~b}$ & $6.59 \mathrm{a}$ & $4.79 \mathrm{a}$ & $34.11 \mathrm{a}$ & $425.0 \mathrm{bc}$ & $31.20 \mathrm{~b}$ & $11.86 \mathrm{~b}$ & $12.33 \mathrm{~b}$ & Vermicompost \\
\hline
\end{tabular}

The means followed by different letters within a column are significantly different $(P<0.01)$.

and total $\mathrm{N}$ content was determined using Kjeldhal method.The P contentwas calorimetrically determined by spectrophotometer (Jackson, 1962). The method of Knudsen et al. (1982) was used for determination of $\mathrm{K}$ in mushrooms by Flame photometer.

\section{Statistical analysis}

The experiment was conducted in factorial format based on a completely randomized design with three replications. A statistical analysis was performed using analysis of variance in the SAS 9.1 software, and means were compared using Duncan's multiple range tests at a $1 \%$ level.

\section{Results and Discussion}

\section{Casing material and thickness effects}

As shown in Table 2, all studied parameters were affected by casing layer except for average weight of mushroom, average cap diameter and dry matter. CCS showed the maximum mushroom yield (27.03 $\mathrm{Kg} \mathrm{m}^{-2}$ ) whereas $\mathrm{CP}$ casing layer had the minimum yield $\left(4.43 \mathrm{Kg} \mathrm{m}^{-2}\right)$. Although difference in yields between $\mathrm{SC}$ and vermicompost casing treatment was not significant, but both were lower than CCS (Table 2). The same results were obtained for total yield of compost and biological efficiency that are two most important criteria for mushroom productivity. In both parameters, compost efficiency and biological efficiency, CCS treatment significantly caused the highest total yield (Table 2).
Number of mushrooms was also significantly affected by casing material. In this matter, no significant difference was observed between CCS and SC (Table2).

The CCS had the significantly lower earliness compared with other casing materials (Table 2). Using $\mathrm{CP}$ as a casing layer delayed the first flush indicating the unsuitability potential for button mushroom production.

The highest average weight of mushroom and the mushroom cap diameter was observed in depth of 4 $\mathrm{cm}$ of casing layer, whereas no significant difference was between depth of 2 and $6 \mathrm{~cm}$ (Figures 1 and 2).

Interaction effects of casing material and its applied depth The interaction effect of two evaluated factors (casing material and casing depth) were significant in average weight of mushroom and mushroom cap diameter. In both parameters $\mathrm{CP}$ casing layer treatment in 4 $\mathrm{cm}$ depth led to the highest record but no significant difference was observed among other treatments (Figures 3 and 4).

No significant differences were observed in phosphorus and potassium concentration of treated mushrooms, but nitrogen concentration was significantly affected by casing material and its depth. The lowest $\mathrm{N}$ concentration was observed in $4 \mathrm{~cm}$ depth of the $\mathrm{CP}$ casing layer that was not significantly different with 2 $\mathrm{cm}$ depth of the CP casing layer (Figure 5). 


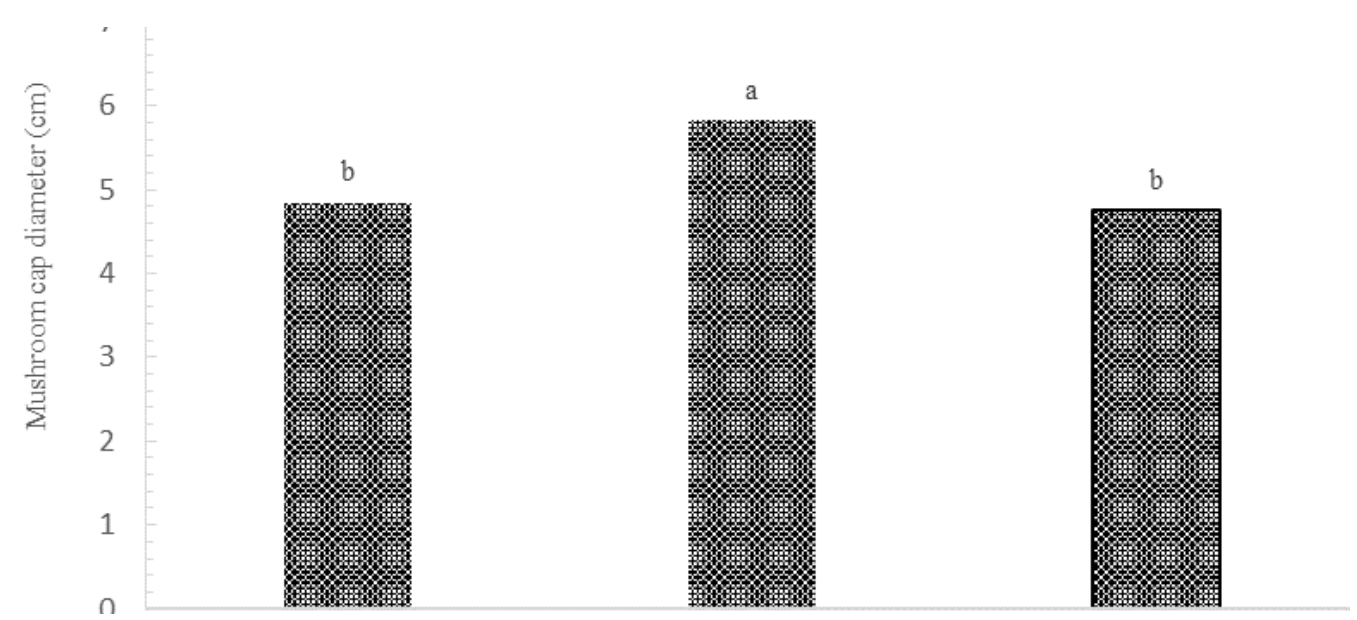

Figure 1: Effect of casing layer depth on the average weight of mushroom.

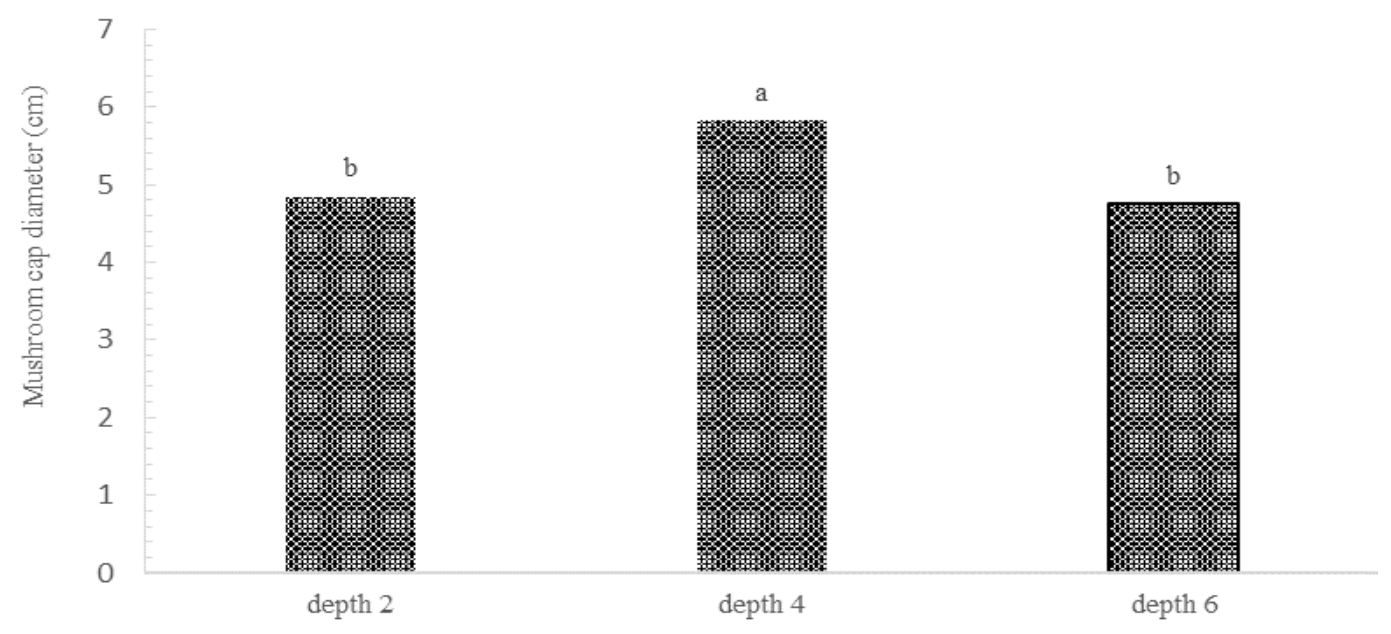

Figure 2: Effect of casing layer depth on the mushroom cap diameter.

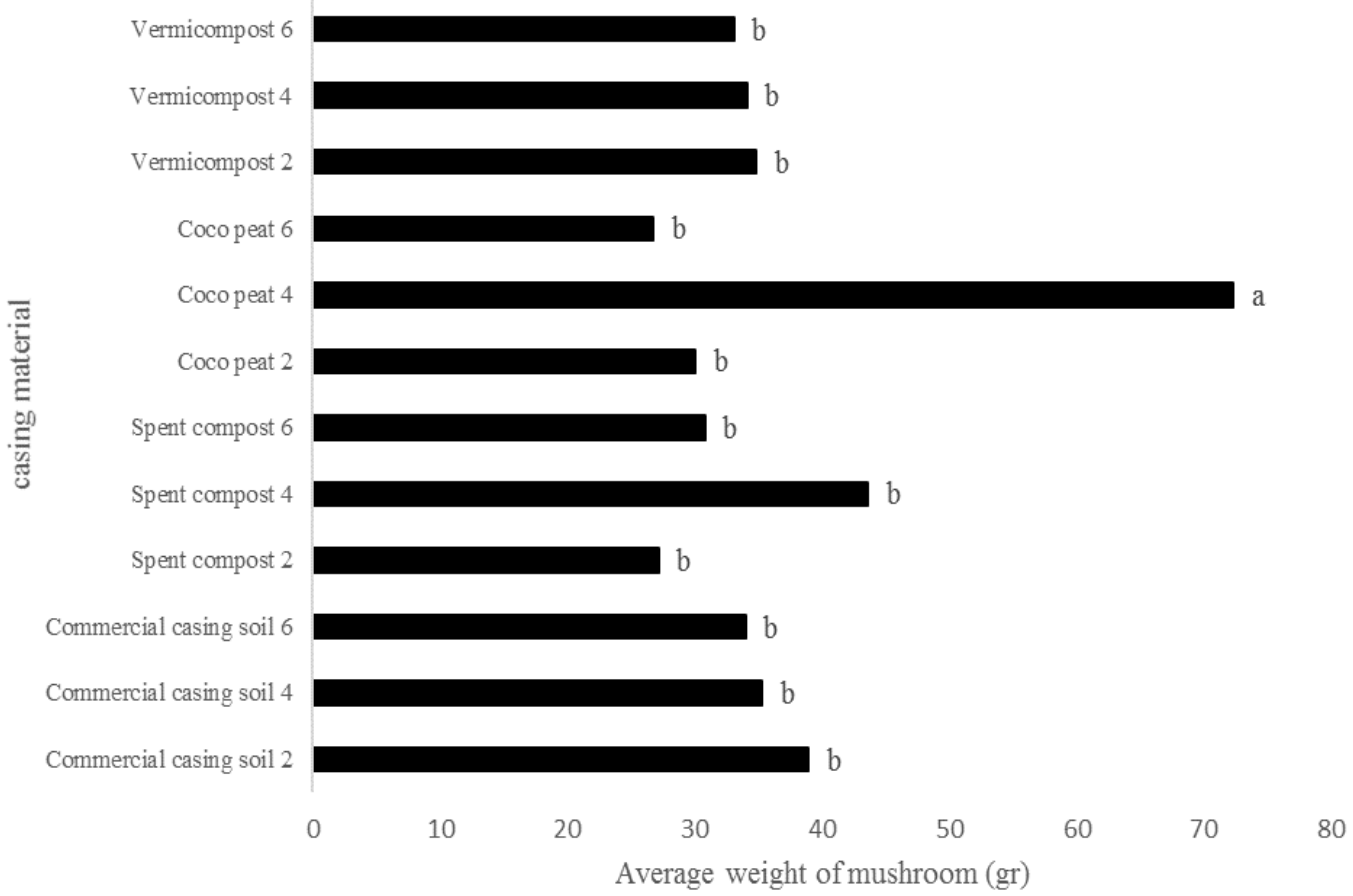

Figure 3: Interactive effect of casing material and depth on the average weight of mushroom. 


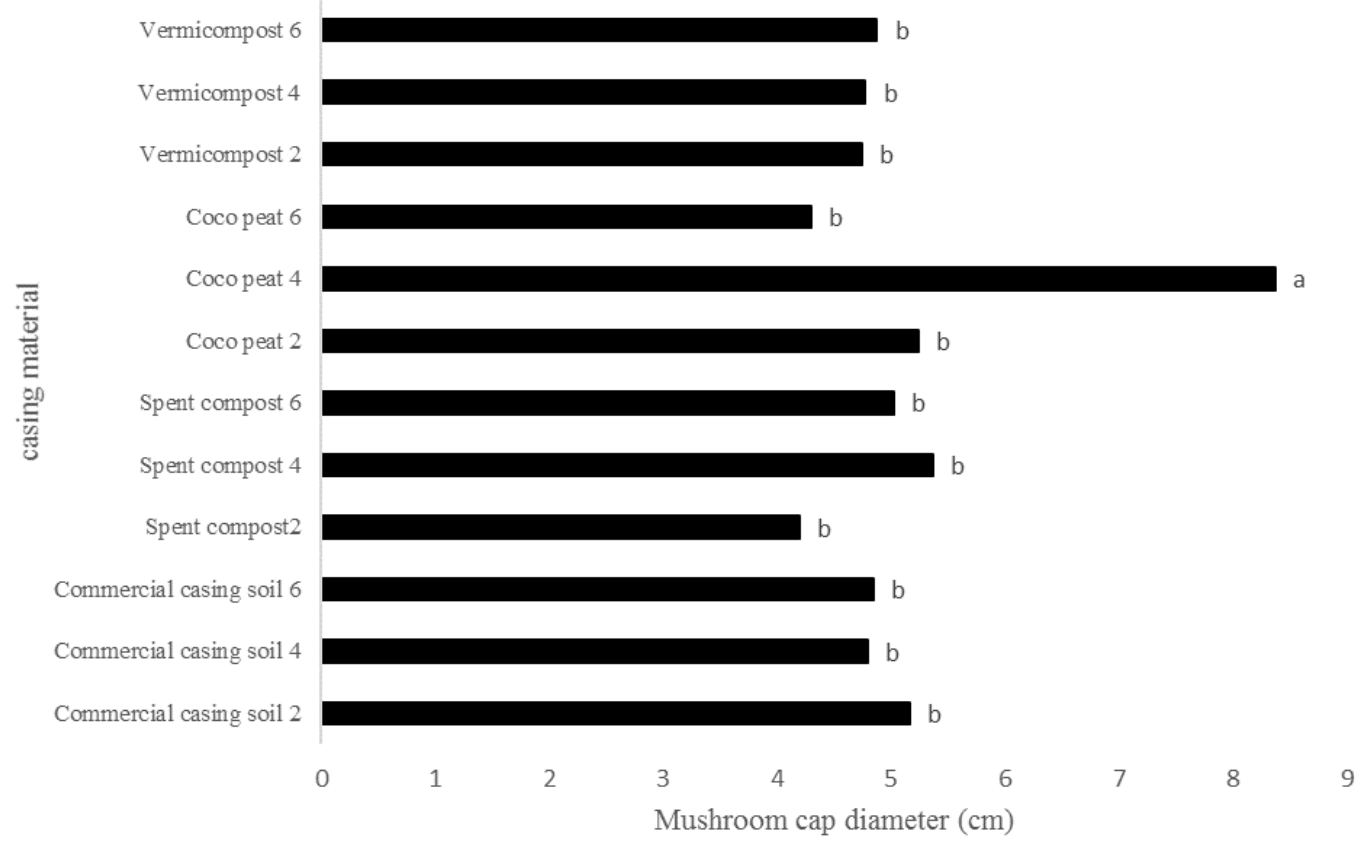

Figure 4: Interactive effect of casing material and depth on the mushroom cap diameter.

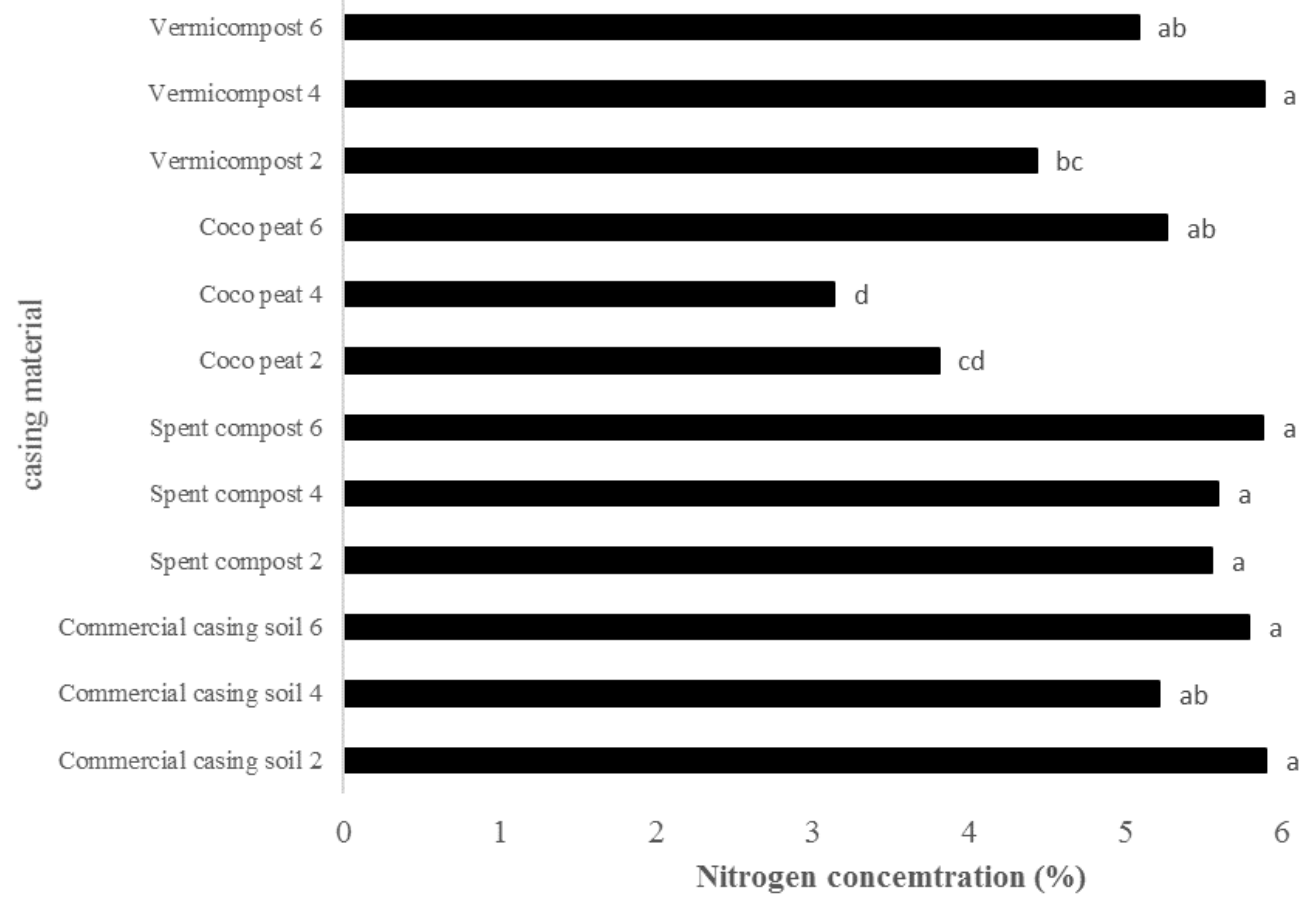

Figure 5: Interactive effect of casing material and depth on the nitrogen concentration of mushroom.

\section{Relation of casing soil characteristics and its function}

As shown in Table 1, water holding capacity of SC is less than CCS, so it may negatively affect SC function. The correlation between $\mathrm{N}$ concentration and the yield and number of mushrooms is positively significant (Table 3). But correlation between $\mathrm{N}$ concentration and average weight of mushroom and average cap diameter were negatively significant (Table 3).

As single effect of casing material showed that $\mathrm{CP}$ treatment can reduce total yield in comparison with other casing materials so it can be attributed to the low number of large mushrooms in $\mathrm{CP}$ casing layer. To find the best casing layer, it is important to consider the water-holding capacity, $\mathrm{pH}$, structure and nutrients of casing material (Oei, 2003). Although vermicompost had high $\mathrm{N}$ concentration and $\mathrm{SC}$ contained high $\mathrm{P}$ and $\mathrm{K}$, however, these casing layers could not affect the yield component of mushroom positively. It shows that mineral elements in casing layer is not essential even can be considered as the limiting factor for growth and yield of button mushroom at least in 
Table 3: Correlation between yield, yield component and nitrogen concentration in button mushroom.

Yield Number of mushrooms in one $\mathbf{m}^{-2}$
Average weight of mushroom
Average cap Nitrogen condiameter

Yield

1

Number of mushrooms in one $\mathrm{m}^{-2}$

$0.936^{* *} 1$

Average weight of mushroom

$-0.122-0.330$

1

$-0.330-0.497^{\text {th }}$

$0.904^{*+}$

$0.518^{* *} \quad 0.521^{*}$

1

$-0.577^{* *}$

$\mathrm{N}$ concentration

$-0.473^{*+}$

Table 4: Economic analysis of the casing material used in this project.

\section{Economical items}

Mean yield $\mathrm{kg}$ per $\mathrm{m}^{2}$

Gross Income (Iranian Rials per $\mathrm{m}^{2}$ )

Price per $1 \mathrm{~m}^{2}$ in depth of $4 \mathrm{~cm}$ (Iranian Rials)

Gross Profit: Gross income-Casing price (Iranian Rials per $\mathrm{m}^{2}$ )

Gross Profit: Gross income-Casing price (US Dollar per $\mathrm{m}^{2}$ )

$\begin{array}{llll}\begin{array}{l}\text { Commercial } \\ \text { casing soil }\end{array} & \begin{array}{l}\text { Spent } \\ \text { compost }\end{array} & \text { Coco peat } & \begin{array}{l}\text { Vermi- } \\ \text { compost }\end{array} \\ 27.03 & 17.71 & 4.43 & 12.33 \\ 2703000 & 1771000 & 443000 & 1233000 \\ 177000 & 0 & 300000 & 530000 \\ 2526000 & 1771000 & 143000 & 703000 \\ 252.6 & 177.1 & 14.3 & 70.3\end{array}$

high concentrations.

The best $\mathrm{pH}$ of casing soil for both Agaricus mycelial differentiation and nutrients availability for Pseudomonas spp. - the aerobic bacteria that stimulate mushroom mycelium to produce primordia- is between 6-7 (Sharma et al., 1996). So, $\mathrm{pH}$ is a little low in $\mathrm{CP}$ (5.85). The primary problem in $\mathrm{SC}$ is high electrical conductivity $\left(\mathrm{EC}=7.52 \mathrm{dS} \mathrm{m} \mathrm{m}^{-1}\right)$. The threshold level of $\mathrm{EC}$ for casing layer was suggested around $1.6 \mathrm{dS} \mathrm{m}^{-1}$ (Pardo et al., 2004) that exceeded for $\mathrm{SC}$. Therefore, it can be suggested that $\mathrm{pH}$ and $\mathrm{EC}$ regulation (by adding lime and leaching respectively) be carried out for optimizing these casing soils.

It has been proved that higher amount of moisture in the casing layer can provide need of mushroom to water (Oei, 2003). Water holding capacity of SC can be increased by adding an appropriate ingredient like $\mathrm{CP}$ which has a remarkable water holding capacity.

There is no scientific evidence about the best casing layer thickness in button mushroom (Agaricus bisporus) cultivation. However, in other edible mushrooms, there is no unanimous idea. Pani (2012) reported that the $2 \mathrm{~cm}$ depth of casing layer for milky mushroom (Calocybe indica) cultivation is the best but Amin et al. (2010) claimed that $3 \mathrm{~cm}$ is suitable casing thickness. It seems that differences in various researches can be due to different casing materials. If the casing be so compact or thick, primordia cannot penetrate through the casing layer inducing the yield increase (Sassine et al., 2005).

The $\mathrm{N}$ content of $\mathrm{CP}$ was more than CCS and SC casing layer (Table 1), however the mushrooms could not absorb $\mathrm{N}$ from casing layer. At least two reasons can be attributed: first, the mushrooms only absorb the nutrients from compost and second, the $\mathrm{N}$ fixation in $\mathrm{CP}$ led to the low availability of $\mathrm{N}$, though the total nitrogen is high. It can be concluded that low $\mathrm{N}$ availability has a key role in size and weight of mushrooms, but it causes reduction of mushroom

Therefore, it can be concluded that high available $\mathrm{N}$ can lead to the high yield through the increasing mushroom number, not mushroom size. Pardo et al. (2002) reported a strong positive correlation between the porosity of the casing layer and the number of button mushrooms, but a negative correlation between porosity and mushroom size.

\section{Economic analysis}

Based on Table 4, there is no payable cost for using $\mathrm{SP}$ as a casing layer but the impact of this material on the yield is extensive. The price of button mushroom in Iran is 100000 Iranian Rial, approximately 1 US \$, so using CCS with $27.03 \mathrm{~kg} . \mathrm{m}^{2-}$ yield results in 252.6 US $\$$ after minus the cost of casing soil. In the same area, SC can just generate 177.1 US \$ income which is meaningfully less than CCS but better than $\mathrm{CP}$ and vermicompost. number and total yield. 


\section{Conclusions and Recommendations}

Selection of casing soil type and its thickness have great impact on yields and yield components of mushroom. Although CCS was the best casing layer in this research, however the reclamation of $\mathrm{CP}$ and $\mathrm{SC}$ in relation to the $\mathrm{pH}$ and $\mathrm{EC}$ potentially make them appropriate for button mushroom cultivation as they are cheap and easily available. In view of initial cost and environmental friendly materials for usage in casing soils, $\mathrm{SC}$ can be recommended as a casing layer, but some decrease in yield should be ignored.

The optimum depth for the casing layer was $4 \mathrm{~cm}$ that can be recommended for button mushroom in comparison with 2 and $6 \mathrm{~cm}$. The $\mathrm{N}$ content in casing materials is more important element than $\mathrm{P}$ and $\mathrm{K}$ for the mushroom optimum growth because high $\mathrm{N}$ concentration led to more yield though the size of mushroom was negatively affected.

\section{Acknowledgments}

This work was financially supported by Sari Agricultural sciences and Natural Resources University (SANRU) as a research project (No. 011397-05). Also, we would like to thank Mr. Yousef Ghasemi for his technical assistance.

\section{Author's Contribution}

Kamran Ghasemi: Head of research team, Statistical analyzer, writer of the paper.

Mostafa Emadi: Chemical analyzer and co-writer Asghar Bagheri and Mehdi Mohammadi: Growing of the mushroom and recording the yield and yield component parameters.

\section{Conflict of interest}

The authors have declared no conflict of interest.

\section{References}

Amin, R., A. Khair, N.Alam and T.S. Lee.2010.Effect of different substrates and casing materials on the growth and yield of Calocybe indica. Mycobiol. 38(2): 97-101. https://doi.org/10.4489/ MYCO.2010.38.2.097

Chapaman, H.D. and P.E. Pratt. 1961. Method of analysis for soil, plant and water. Univ. Calif. River Side, USA. pp. 309.
Colauto, N.B., A.R., da Silveira, A.F., da Eira and G.A. Linde. 2010. Alternative to peat for Agaricus brasiliensis yield. Bioresour. Technol. 101: 712-716. https://doi.org/10.1016/j. biortech.2009.08.052

Flegg, P.B., D.M., Spencer and D.A., Wood. 1985. The Biology and Technology of the Cultivated Mushroom. John Wiley and Sons, Chichester.

Gulser, C. and A. Peksen. 2003. Using tea waste as a new casing material in mushroom Agaricus bisporus (L.) cultivation. Bioresour. Technol. 88: 153-156. https://doi.org/10.1016/S09608524(02)00279-1

Knudsen, D.G.A. and P.F. Pratt. 1982. Lithium, sodium and potassium. In: page, A.L. et al. (Eds.), Methods of soil analysis (Part 2), Chemical and microbiological prosperities, Agronomy monograph No 9, second ed. ASA-SSSA, Madison, WI, USA.

Noble, R. and A. Dobrovin-Pennington. 2005. Partial substitution of peat in mushroom casing with fine particle coal tailings. Sci. Hortic. 104: 351-367. https://doi.org/10.1016/j.scienta.2004.09.004

Oei, P. 2003. Mushroom Cultivation. $3^{\text {rd }}$ Edition. Backhuys Publ. Leiden, The Netherlands.

Pani, B.K. 2012. Sporophore production of milky mushroom (Calocybe indica) as influenced by depth and time of casing. Int. J. Adv. Bot. Res. 2(1): 168-170.

Pardo, A., J.A. De-Juan and J.E. Pardo. 2002. Bacterial activity in different types of casing during mushroom cultivation Agaricus bisporus (Lange) Imbach. Acta Aliment. 31: 327-342. https:// doi.org/10.1556/AAlim.31.2002.4.3

Pardo, A., M.J. Navarro, M.J. Lopez and F.J. Gea. 2004. Uso del compost agotado de hongos cultivados reciclado como material de cobertura para el cultivo de champiñón. In: Agroecología: Referente para la transición de los sistemas agrarios. Proc. VI Congreso de la Sociedad Españolade Agricultura Ecológica, 27 Sept-2 Oct. Almería, Spain. pp. 1599-1609. [In Spanish].

Pardo-Giménez A. and J.E. Pardo-González. 2008. Evaluation of casing materials made from spent mushroom substrate and coconut fibre pith for use in production of Agaricus bisporus (Lange) Imbach. Spanish J. Agric. Res. 6(4): 683-690. https://doi.org/10.5424/sjar/2008064-361

Nadi, S., M. Farsi, S.H. Nemati, H. Aroiee and G.H. Davarnjad. 2015. Recycling of Casing 
Soil in The White Button Mushroom (Agaricus bisporus) production. J. Hortic. Sci. 28(4): 446452.

Rainey, P.B. and A.L.J. Cole. 1987. Space-for-air, the key to a productive casing. Mushroom J. 178: 310-311.

Sassine, Y.N. and Y., Ghora, M. Kharrat, M. Bohme and A.M.R. Abdel-Mawgoud. 2005. Waste paper as an alternative for casing soil in mushroom (Agaricus bisporus) production. J. Appl. Sci. Res. 1: 277-284.

Sharma, H.S.S., D. McCall and G. Lyons. 1996. Chemical changes in peat as a result of neutralizing with lime during the preparation of mushroom casing. In: D.J. Royse (ed), Mushroom biology and mushroom products: 363-
372. Univ. Park.

Subramanian, K. and K. Shanmugasundaram. 2015. Optimization of casing process for enhanced bioefficiency of Calocybe indica, an indigenous tropical edible mushroom. Int. J. Recent Sci. Res. Res., 6(2): 2594-2598

Jackson, M.L., 1962. Soil chemical analysis. Prentice Hall of India, New Delhi.

Zied, C.D., A. Pardo-Gimenez, M.T. de Almeida Minhoni, R.L. Villas Boas, M. Alvarez-Orti and E. Pardo-Gonza'lezJ. 2012. Characterization feasibility and optimization of Agaricus subrufescens growth based on chemical elements on casing layer. Saudi J. Biol. Sci. 19: 343-347. https://doi.org/10.1016/j.sjbs.2012.04.002 